\title{
The Female Subjectivity Constitution: A Look by Freudian Bias
}

\author{
Henrique Guilherme Scatolin \\ PUC-SP (Pontificate Catholic University of São Paulo), São Paulo, Brazil
}

\begin{abstract}
From a singular reading on Freudian metapsychology, this article aims to conduct a literature review on the female subject psychic constitution, pointing out to the main concepts developed by Freud for his understanding. In order to achieve such result, this article departs from the satisfaction experience, highlighting the parents' desire for this child while being a singular subject, passing by the impulse, narcissism, and self-eroticism concepts. Parallel to these concepts development, a child pre-genital and genital organizations reading is made, focusing on the Oedipus complex interlacing with the female sex castration, noting the infantile repression effect on infantile sexuality; as well as the superego formation and the possible identifications after the Oedipal complex dissolution. It is concluded that, for the Freudian psychoanalysis, it is imperative to relieve the articulation between the castration complex and Oedipus complex to understand the psychic destinations of each subject.
\end{abstract}

Keywords: female psychic constitution, satisfaction experience, penis envy, desire to have children

This article aims to address the female psychic subject constitution according to the Freudian theory. For this purpose, it is necessary to go through the Viennese master early studies on the psychic constitution.

At the end of the 19th century, the time corresponding to the start of psychoanalytic theory pillars, Freud is at the beginning of his study on the psychic subject constitution. When writing the letter number twenty-four to Fliess, Freud (1895) notes:

After periods of ten to eleven hours with the neurosis... I am tormented by two objectives; examine what form the mental functioning theory will assume... and, secondly, extract from psychopathology a profit for the normal psychology. Actually, it is impossible to have a satisfactory general conception of neuropsychotic disorders if you cannot link it to clear assumptions about the normal mental processes.

So, in 1895, Freud is in the early days of the studies on the neurotic and normal processes. That same year, he focuses, on the text Project for a Scientific Psychology (Projeto para uma Psicologia Científica), the importance of another presence, usually the mother, at the beginning of the baby's life, for his psychic development.

According to Freud, in the psychic apparatus origin, the tension state present in the baby body, generated by the hungry tries to be released by means of a motor discharge, such as screaming and crying; but no motor discharge leads to a result of his internal tension relief. The newborn body is incapable of a specific action that extinguished the tension state, needing the help from another person. That is, of a foreign help, from his mother (or from a substitute) through a specific action. In this way, the satisfaction experience puts an end to the child internal tension through the mother (or substitute) external aid to her son, having this experience more radical implications in the development of an individual functions.

Henrique Guilherme Scatolin, Master, PUC-SP (Pontificate Catholic University of São Paulo). 
Freud resumes the experience importance in the psychic constitution satisfaction in Chapter VII of his book The Dreams Interpretations (A Interpretação dos Sonhos). In this famous book, Freud notes that the satisfaction experience introduces the baby desire, conceiving the desire as "a psychic notion which will seek the re-cathexis of mnemonic image perception and revoke the own perception, which is to reestablish the original satisfaction situation” (1900, p. 595). He postulates that only desire is capable of putting the psychic apparatus in motion, in accordance with the pleasure principle. Thus, in the psychic constitution a first moment, when the internal tension state created by the need arises again, the satisfactory object image is reinvested as the desire hallucinatory satisfaction.

But when publishing the text Formulations on Mental Functioning Two Principles (Formulações Sobre os Dois Princípios do Funcionamento Mental), Freud (1911) points out:

It will be objected that an organization that was slave of the pleasure principle and disregarded the external world reality could not keep alive, even for a shorter time... The use of a fiction like this, however, is justified when one considers the baby—provided that he contains the care received from the mother—almost performing a psychic system of this kind. (p. 238)

Freud, in this quotation, is referring to the reality principle introduction in the baby psychic constitution first moments. So, after the satisfaction experience, as there is an increasing requirement of internal needs and, consequently an absence of expected satisfaction, the child abandons this satisfaction attempt through the hallucination. And due to the lack of satisfaction through the hallucination, a new principle of mental functioning is started: the reality principle.

After the first satisfaction experience, the child desired is established, the Viennese master stresses the newborn maternal cares importance. In 1905, in the Three Essays on Sexuality Theory (Três Ensaios Sobre a Teoria da Sexualidade), he reiterates the importance assigned to the other, who usually is the maternal figure, in the child sexuality establishment. Thus, Freud (1905) states that:

The child deals with the person who assists him, for him, a constant source of excitement and sexual satisfaction from erogenous zones, and even more if this person, usually the mother, admires the child with the feelings derived from her own sexual life: she touches, kisses and cradles, and it is perfectly clear that she treats him as the replacement of a fully legitimate sexual object... She (the mother) is awakening the her son sexual impulse and preparing its later intensity. (pp. 210-211)

The mother (or someone who replaces her), when taking care of the baby caressing and kissing him, is awakening his sexual impulse or libido. The mother (or someone who represents her) offers an endless source of sexual excitement and satisfaction of erogenous zones for her child.

And when referring to the life and death impulse presence at the child early psychic constitution, Freud (1923) postulates that life emergence would be, then, the life continuation and also, at the same time, the effort towards death. And life itself would be a conflict and a reconciliation of these two inclinations. These two inclinations are two impulse classes that coexist since birth: the life impulse (sexual impulse or libido and self-preservation impulse) and the death impulse (destructive impulse, domain, or power will). Life consists of conflict manifestations or the interaction between these two impulsive classes, i.e., between life impulse (Eros) and death impulse (Thanatos).

These two impulse classes are present in human psyche, but Freud (1924) notes that, at the beginning, "the libido has the mission to make the destructor instinct innocuous and performs it diverting this instinct, mainly, 
outside... with the aid of a special organic system, the muscular apparatus” (p. 181). The death impulse deviation to the external environment is essential for the psyche constitution. The life impulse aims to make the destructive and aggressive impulse harmless, partially directing it outside and, partially, by mixing with it.

During the first maternal cares that the individual sexual impulse arises, Freud (1905) points out:

The child lips behave as an erogenous zone, and the stimulation by the warm milk was, no doubt, the source of pleasurable sensation.... Sexual activity primarily relies on one of the functions that serve for the life preservation, and only later becomes independent from them. (p. 171)

Early in life, the baby's sexual pleasure comes from the moth-lips excitement, the tongue. At this time, sexual activity can be related to milk intake, the lips stimulation, etc..

In addition to providing that sexual pleasure, the affectionate relationship between baby and mother becomes a model for all loving relationships in the individual life. Freud (1905) declares that the object encounter (at puberty) is, in fact, a re-encounter. This means that even after the sexual activity is separated from the nutrition act, a significant portion remains to prepare the boy and girl to the puberty object choice, being this object encounter a re-encounter of the old love object abandoned in remote childhood, after the Oedipus complex resolution.

From birth, the Viennese master underlines the parents' presence importance (and not only the mother) on the son psychic constitution. In relation to this presence, Freud (1914) explains:

So they (the parents) are under the compulsion of assigning all perfections to the son... and hiding and forgetting all his deficiencies... He will once again really be the center and the creation essence-“His Majesty the Baby”... The child will materialize his golden dreams that parents have never realized... The parents love, so touching and in fact so childish, is nothing more than the parents narcissism reborn, which, transformed into love object, unmistakably revels its previous nature. (p. 97)

For Freud, concomitantly to the mother presence, the father is also present since the child early psychic constitution. The child birth represents for the couple (here understood as father and mother) a revival of their own narcissism that had been long abandoned. So, mom and dad relieve the old childish narcissism with their child birth, assigning all the world perfections to this new son, and denying his faults and imperfections.

According to the Freudian metapsychology, in addition to the parents' old narcissism revival with the son birth, the self-eroticism and the narcissism deserve a brief highlight in the male subject psychic constitution.

In a letter to Fliess, Freud (1899) already defined the self-eroticism as a lower sexual layer... that acts without any psychosexual objective and only requires the local sensations of satisfaction.

Six years after writing this letter, Freud writes the Three Essays. In this brilliant book, which caused (and still causes) criticism to psychoanalysis, Freud (1905) expresses that, in early life, the impulse was not directed to another person; it is satisfied in the own body, it is the self-erotic. That is, the baby presents the mode by which sexual impulse finds satisfaction in his own body. And this mode is referred to as self-eroticism.

It is necessary to point out that, for Freud (1914):

A unit comparable to ego cannot exist in the individual since the beginning; ego has to be developed. The self-erotic impulses, however, have been there since the beginning, and therefore, it is necessary that something is added to the self-eroticism—a new psychic action—in order to provoke the narcissism. (p. 84)

Thus, the self-eroticism, i.e., the mode by which the impulse seeks satisfaction in the subject own body, is present since the beginning. Narcissism is the result of a new psychic action which would be added to 
self-eroticism.

Although not specified in the text Regarding Narcissism: An introduction (Sobre o Narcisismo: uma introdução) (1914) what is this psychic action, in the article The Impulses and Its Vicissitudes (As Pulsões e as suas Virtudes), Freud (1915) says:

We are used to denote the ego development initial phase, during which the sexual instincts find self-erotic satisfaction, of "narcissism".... At the very beginning of life, ego is the cathexis with the instincts, being, to a certain extent, able to satisfy them in ourselves. We call this "narcissism" condition, and this form of obtaining satisfaction, "self-erotic". (pp. 137-139)

In this text, he understands narcissism as a first way in which ego is constituted, because thanks to "his majesty, the baby"; the child's ego is organized in its early form as an ideal ego, narcissistically invested by libido and which masterpiece the boy is not willing to renounce during his childhood. Thus, the ego is a unit that does not exist since the psychic constitution beginning, needing to become, as an ideal ego, narcissistically invested by the parents.

It seems necessary to point out that for Freud, before the ideal ego resulting in narcissism, the ego is "first and foremost, a body ego; and not simply a surface entity, but it is... the projection of a surface” (Freud, 1923, p. 42). In the psychic early constitution, the newborn is provided of an id and, then, a body ego, targeting to the establishment of an ideal ego narcissistically invested.

On the subject psychic constitution, in addition to the ideal ego presence, it is necessary to point out the role played by pre-genital organizations.

In libidinal development level, Freud (1905) postulates that during the early years of a child's life there are organizations in which the genital areas have not assumed its predominant role. These organizations are defined as pre-genital organizations in which the impulses are partial and which objective is the satisfaction by means of appropriate stimulation of erogenous zone.

Freud (1905) defines erogenous zone as a part of the skin or the mucosa where certain types of stimulation cause pleasurable feeling of certain quality. These dominant areas are, respectively, the mouth in the oral phase and the anus in the anal phase. Still, according to Freud (1905), the first of these pre-genital sexual organizations is the oral, or... cannibalistic. In this the sexual activity has not yet separated from nutrition, nor the differentiated opposing currents inside it.

In this organization, sexual activity is related to the nutrition and which erogenous dominant zone is the mouth. During this organization, the child feels pleasure sucking the mother breast. That is, at the beginning of the baby's life, the psychic activity focuses on providing satisfaction to oral zones needs, such as sucking the milk from the mother breast and subsequently sucking (somehow) another object that replaces the breast, such as the finger or pacifier. The act of sucking on the mother breast is the first activity that provides pleasure to the baby, where his lips behave as an erogenous zone. Thus, sexuality begins to manifest in the baby and after breastfeeding, when he starts sucking the breast, finger, or pacifier.

During the oral organization, Freud (1905), declares that the sexual target consists in the incorporation of the object, model that later will play, in the form of identification, a psychic important role.

For Freud, the second pre-genital organization is the anal-sadist which dominant erogenous zone is the anal. In this organization, Freud (1905) says:

The intestinal contents... have for the breastfeeding other important senses. It is obviously treated as a part of his own 
body, representing the first "gift". When disposing of it, the little creature can express docility to the environment surrounding him, and when refusing it, his stubbornness. (p. 176)

During the anal-sadistic organization, the faeces represent the first gift that the child can give someone that he likes, demonstrating his obedience. If he denies giving the faeces, he is expressing his stubbornness.

Freud explains that "the fecal mass retention, at first intentionally practiced to take advantage of the stimulation as an anal zone masturbatory... and, incidentally, one of the causes of constipation so frequent in neuropaths" (1905, p. 176). The fecal mass retention during childhood may be related to masturbatory stimulation of anal zone, as he can also be demonstrating his pertinacity in the relationship with the people who take care of this child. And when growing, this game of retaining faeces may be symbolically present in the special scatological rituals, in ceremonial acts and similar acts which are carefully kept confidential by the neurotic individual.

Freud (1913) points out that in anal-sadistic organization the genital zones primacy has not yet been established. On the contrary, the instinct components that dominate this pre-genital organization of sexual life or the anal-erotic and sadistic.

In a note added to Three Essays, Freud (1905) recognizes that in this organization the division into opposites that pervades the sexual life is already constituted, but they still cannot be called masculine and feminine, but active and passive. During this pre-genital organization, the active inclination is filled by the domain instinct that Freud calls sadism and the passive inclination is fueled by the anal eroticism. A fortification of anal eroticism allows an inclination to homosexuality in males when the genitals primacy is achieved.

On the New Conferences (Novas Conferências), Freud (1933) notes that:

The attitude towards the libido organization phases has changed a bit.... Whereas, previously, it mainly emphasized the way how each phase passed before the next phase, our attention, now, is directed to the facts that show how much of each prior phase still continues in the subsequent configurations.... (p. 102)

Namely, the predominance of one phase in relation to the other does not occur so suddenly, but gradually, since parts of the previous organization always coexist side by side the latest.

In another footnote added to Three Essays (Três Ensaios), Freud (1905) revels that "after the two pre-genital organizations, there is a third phase in child development: this, that already deserves the name of genital... knows only one type of genitalia: the male. For this reason I called it the organization phallic phase" (1905, p. 188). The third organization described by Freud is the infant genital organization, in which, to the phallus primacy, is also called phallic phase. In this phase culminate the Oedipus complex and the castration complex.

For the Viennese master:

The main characteristic of this "infant genital organization" is its difference from the adult final genital organization. It consists in the fact that, for both sexes, only one genital organ is considered, namely, the male. What is present, therefore, is not a priority of the genitals, but the phallus primacy. (Freud, 1923, p. 158)

At this phase, both the boys and the girls only recognize one genital organ: the male. The observation of this organ is of utmost relevance, since the losing fantasy traces different destinations in both sexes: if, for the girl, the castration anxiety that launches her on the Oedipus complex, for the boy, it is the same anxiety that "demolishes" this complex. For a better understanding of how this complex, articulated to the castration complex, occurs in the female, we would like to turn to the Oedipus complex in females. 


\section{Female Oedipus Complex}

In the text The Infant Genital Organization (A Organização Genital Infantil) (1923) Freud no longer addresses the idea of symmetry between the male and female Oedipus complex, and points out that the phallus primacy, in the phallic phase, is of extreme relevance to the individual psychic destiny. In the author's understanding, the castration will focus on this primacy (both in the boy and girl) breaking the false narcissistic illusion of being the response to maternal desire. And when finishing this article, he points out that he "can only describe this state of things at the point at which it affects male child; the processes... in the girl we do not know” (1923, p. 180). Thus, the female Oedipus complex was still unknown at this time and, over the subsequent years; he devoted special attention to it.

In 1924, the master states that "The girl Oedipus complex in girls is much simpler than the penis small carrier” (1924, p. 119). At this time, the girl desires to assume the space occupied by her mother, assuming a female attitude in relation to the father. Not satisfied with this observation, and rethinking the articulations game of positive and negative sides in this complex, Freud, in 1925, points out the castration anxiety importance.

Such observation occurs in the article Some Psychic Consequences of Anatomical Distinction Between the Sexes (Algumas Consequências Psíquicas da Distinção Anatômica Entre os Sexos) in which he brings an articulation between the Oedipus complex and castration complex (and, consequently, with the phallic phase). In the case of the girl, the castration complex inserts her on the Oedipus complex, taking her from a negative side in relation to the mother and playing in a positive relation regarding the father. In these intricacies, castration anxiety is settled in the girl due to the fact of missing this organ: In her fantasies, the penis was withdrawn, leaving her out of this organ. About this, Mijolla understands that "Girls are castrated boys as a punishment for her incestuous desires and masturbation” (2005, p. 373).

Due to the fact of being deprived of this organ by her mother, the girl seeks reparation with the father. Thus, when discovering her organic inferiority, it is with much hesitation and reluctance that the girl accepts this unpleasant knowledge and imagines that one day she will be able to have this organ. Consequently, this leaves a negative relation with the mother, displacing to a positive Oedipal relationship with the father.

In these disconnection mishaps, the master introduces the penis envy issue to girls, as well as the desire to have children. This means that, when she discovers she is deprived of this organ, the girl disconnects from the mother and seeks the different sex (the father), expressing the desire to have a son with him, while in the past she wished to have one from her mother. Thus, the Oedipal complex entire development is concrete in the penile envy shadow.

Here it is interesting to note that the mother is a common and first element at the male and female Oedipus complex beginning. Both the boy and the girl should renounce this object, once the castration anguish makes both see as castrated, collapsing the maternal phallus. If, on the other hand, the girl comes to refuse such a perception, such fact could generate the psychosis; but, if on the other hand, she accepts it, she can be taken by the penis envy, since her mother deprived her from this organ, and the only one who could provide it would be her father. So, against this envy, the girl turns away resentful of the mother for the damage caused and in search of her father for the desire of having a penis and, subsequently, the desire to have a son with him, becoming "a little woman” (Freud, 1925, p. 318).

According to Freud, the positive Oedipus complex in women "can be slowly abandoned or dealt with 
repression, and its effects can persist with a lot of emphasis on women mental life” (1925, p. 319). At this point, The author believes that the master already alludes, indirectly, to the fear of maternal love loss as a primary factor in the female Oedipus complex resolution.

Six years were not enough for Freud examining this complex specificity deeper. In his article Female Sexuality (Sexualidade Feminina), he highlights that the recognition of female castration opens three psychic possible destinations.

The first possible way would be the general revulsion to sexuality. This means that the girl scarred by the comparison with the boys, grows dissatisfied with her clitoris, abandoning her phallic activity and, with it, her general sexuality. This girl lived in a male way: She could get pleasure from her clitoris, keeping this activity in relation to her wishes directed to the mother. Thus, her homoerotic love was directed to the phallic mother and when she discovers this is castrated, it becomes possible to abandon her as an object, creating a hostility relationship.

The second path, through the castration anguish, would be the masculinity complex. This makes the girl to adopt a challenging measure regarding her threatened masculinity, holding on the hopes of getting a penis in any occasion. She refuses to recognize the fact observed and, in a defiant manner, becomes involved with her clitoral activity and refuges in an identification with her phallic mother of with her father. It would be in this hope that the fantasy of being a man persists, resulting, from this complex, the choice of her manifest homosexual object. Therefore, if a girl persists in the desire to turn into a boy, she will end up a manifest homosexual, or, in some cases, she may present traits for men through her adult genital organization.

If the Oedipus complex development follows a third path, the girl will achieve a normal female normal attitude, making the father as the desire object and thus finding a path to the Oedipus complex feminine form. At this time, the girl leaves the mother she loved, since she cannot forgive her for having her deprived of a penis, and puts the father as her love object. And when losing the old love object, the girl identifies with her, occupying the place of this ancient connection. This means that, when putting on the mother place, she tries to take her place with the father, being the hatred a result of this link. This hatred comes from the penis envy and mortification which was denied to her.

So, the girl goes towards the father wishing to have a penis that she was deprived, although such desire leads to another desire: of having a baby from him as a gift. At this moment, the desire to have a baby will occupy the former desire to have a penis.

For Freud (1931), in women, "The Oedipus complex constitutes the final result of a quite lengthy development. This is not destroyed, but created by the castration influence” (p. 238). The rivalry attitude with her mother originates before from the female Oedipal complex, being strengthened and exploited in the Oedipal situation.

This distance from the mother is "a very important step in the course of a girl development” (Freud, 1931, p. 247). The girl in the positive Oedipus complex leads to a change in the loving object (from the mother to the father), as well as a change in the erogenous zone (from the clitoris to the vagina). As in psychoanalysis there is no overcoming of a previous phase to the next one, in the case of women, the oral, anal, clitoral, vaginal, and body eroticism are present in sexual pleasure, and it is not correct to say that the clitoral pleasure should be overcome by the vaginal.

The pleasure obtained by the pleasurable sensations of clitoral handling is reintegrated in the article titled Femininity (Femininidade), when the master says: "The little girls do the same with her small clitoris. It seems 
that, in all of the, the masturbatory activity is performed in this equivalent to the penis, and that the truly feminine vagina, at this time, has not been discovered yet by both sexes” (1933, p. 118). In the phallic phase, the clitoris is the primary erogenous zone and, if the girl goes towards femininity, this pleasure is displaced to the vagina.

So, during the infant genital organization, the girl needs to change her erogenous zone (from clitoris to vagina) and object (from mother to father), although the pre-Oedipal link with the mother is of extreme relevance to the understanding of adulthood conflicts. Consequently, the distance from the mother can end in hatred, since this object change comes with hostility, since this mother deprived the organ that she desires.

According to Freud, the girl can only progress to assume her femininity if this desires to obtain the father penis is replaced by the desire to have a baby, making this baby a symbolic equivalent to the old penis that one day she wished to obtain. Therefore, with the transfer to the father of the penis-baby desire, the girl starts the Oedipus complex situation, fortifying the hostility against her mother, since this rival received from the father what the girl one day wanted to have. That is why reaching femininity supposes three phases.

The first phase proposes that the castration recognition leads the girl to resent her mother for not giving her a penis, going away from her with hostility, although she keeps the love-hate ambivalence with her. In the second phase, she is taken by the penis envy, searching for the father. In the third and final phase, this girl turns to her father in order to win a penis that the mother refused. Consequently, the female situation will come true if the desire to have the penis is replaced by the desire to have a baby, making this baby to assume the penis place.

According to Freud, in the girl, "The Oedipal situation is the result of a long and hard evolution; it is a kind of preliminary solution, a rest position that is not soon abandoned, especially because the latency period beginning is not so far" (1933, p. 128). So, the girls remain in the Oedipus complex for an indeterminate time, they destroy it belatedly and, yet, "incomplete" (1933, p. 129). Due to this, the superego does not reach intensity, such as it occurs with the boys.

In Anxiety and Instinctive Life (Ansiedade e Vida Instintual), Freud (1933) takes up this demolition, stating:

The castration fear is not, of course, the only reason for repression: In fact, it does not happen with women, because, although they have a castration complex, they cannot have fear of being castrated. In her sex, what happens is the fear of maternal love loss, which is, evidently, a later extension of the child's anxiety when noticing the mother absence. (p. 90)

Therefore, to the psychoanalysis father, what leads a girl to an end to her Oedipus complex, establishing the superego is the fear of maternal love loss.

However, it should be pointed out that humans sex life has a apex from three to five years of age, declining around this age, being followed, first, by a latency period and, subsequently, by the adult genital organization.

During this organization, Freud (1940) declares that "Little loss is caused to a woman if she stays in her feminine Oedipal attitude” (p. 207). Thus, in her adulthood, she may choose the husband by her paternal characteristics, recognizing his authority. The old desire to possess a penis is supported if she is successful in the choice of this loving object, extending her love to the organ carrier.

\section{Ego Ideal and the Superego}

When referring to the ego ideal formation, Freud (1914) states: 
For the ego, the formation of an ideal would be a conditioning factor of repression.... What the subject projects towards himself as being his ideal (of ego) is the replacement for narcissism lost in his childhood in which his own ideal was.... The ego development consists in the removal of his primary narcissism.... This distance is caused by the libido displacement towards an externally imposed ego ideal. (pp. 100-102)

Thus, during the pre-genital and infant genital organization there is a narcissistic invested ideal ego. Due to the castration anxiety during the phallic phase, there is the infantile sexuality and ideal ego repression, which heirs are, as stated in the previous paragraph, the superego and the ideal ego. This ideal ego is the narcissism replacement lost in childhood.

When writing The Ego and the Id (O Ego e o Id), Freud (1923) stresses that the differentiation with the ego can be called "ego ideal" or "superego". At this time, Freud uses both concepts interchangeably, but it is only in the New Conferences (Novas Conferencias) that he elaborates a differentiation between superego and ideal ego. In these conferences, Freud (1933(1932)) declares that superego is:

The ego ideal vehicle, by which the ego is evaluated, that stimulates it and which requirements for perfection are always greater than what he strives to accomplish.... This ego ideal is the precipitate of the parents old image, the admiration expression that the child so attributed to them. (p. 70)

It is understood that Freud imputes to the superego a function of being the ego ideal vehicle responsible for the perfection pursuit, and the superego for the ego ideal maintenance. Its functions are the self-observation, the consciousness, and the maintenance of this ideal. On the other hand, the ego ideal has the function to stimulate the ego to achieve perfection and serve as an instrument through which ego evaluates itself.

On superego formation, Freud (1924) considers that the father or both parents authority is introjected in ego, and there forms the superego core, which assumes the father severity and perpetuates this prohibition against incest, thus defeating the ego of libidinal cathexis return. Superego retains the strength, severity, and the inclination to punish that is inherited from parents. This psychic instance protects the ego against the incestuous desires return.

For Freud (1933):

The child superego is, in fact, built not according to the his parents model, but his parents superego... It becomes a tradition vehicle and all of long lasting value judgments that this way were transmitted from generation to generation. (p. 69)

Then, the superego of a boy is above all, a psychic instance when the values that go beyond his parents' superego are present, since the values and judgments are transmitted from generation to generation.

After the latency phase (where we found the superego formation according to the Freudian conception), there begins the adult genital organization. In this organization, the "(Oedipus) complex is unconsciously revived and involved in new modifications" (1924, p. 263). At puberty, man revives in his unconscious the old Oedipal complex repressed in his early childhood. In this organization, the sexual impulses are in the reproduction service. During puberty that one can establish a clear separation between the male and female characters, establishing the genital areas primacy was not possible in the child genital organization. At this phase, the woman can present an object choice of analytical or connection object type, since during her puberty when the adult sexual life final configuration occurs, when the object encounter is consummated, which had been prepared from the most remote childhood. 


\section{Conclusion}

Throughout this article the core concepts linked to psychic constitution of female subject in Freudian theory were crossed, but it is necessary to highlight that due to the Oedipal complex articulation with the castration complex, each subject may present three possible exits for his infantile sexuality, i.e., three psychic destinations: neurosis, psychosis, and perversion. While that, for Freud (1924), in neurosis there is the castration recognition, in psychosis occurs the refusal of this, being the delirium a bridge to the reality exclusion. And in perversion there is a recognition, and the castration refusal, being the fetishism its prototype.

Therefore, before making a diagnosis of each clinical case, the psychotherapist is entitled to recognize his patient in the symptom singularity, listening to his libidinal and identificatory story. It is from his listening that the concepts listed above will create liveliness in the clinical practice, allowing the construction of a clinical listening.

\section{References}

Freud, S. (1899/1996). Letter of December 9. ESB, I. Rio de Janeiro: Imago.

Freud, S. (1900/1996). A interpretação dos Sonhos. ESB, V. Rio de Janeiro: Imago.

Freud, S. (1905/1996). Três ensaios sobre a teoria da sexualidade. ESB, VII. Rio de Janeiro: Imago.

Freud, S. (1908/1996). Caráter e erotismo anal. ESB, IX. Rio de Janeiro: Imago.

Freud, S. (1908/1996). Sobre as teorias sexuais das crianças. ESB, IX. Rio de Janeiro: Imago.

Freud, S. (1911/1996). Formulações sobre os dois princípios do funcionamento mental. ESB, XII. Rio de Janeiro: Imago.

Freud, S. (1912/1996). Contribuições a um debate sobre a masturbação. ESB, XII. Rio de Janeiro: Imago.

Freud, S. (1913/1996). The inclination to obsessional neurosis-A contribution to the neurosis issue. ESB, XII. Rio de Janeiro: Imago.

Freud, S. (1914/1996). Sobre o narcisismo: Uma introdução. ESB, XIV. Rio de Janeiro: Imago.

Freud, S. (1915/1996). Os instintos e as suas vicissitudes. ESB, XIV. Rio de Janeiro: Imago.

Freud, S. (1915/1996). Repressão. ESB, XIV. Rio de Janeiro: Imago.

Freud, S. (1917/1996). Conferência XIX-Resistência e repressão. ESB, XVI. Rio de Janeiro: Imago.

Freud, S. (1920/1996). Psicologia de grupo e a análise do Ego. ESB, XVIII. Rio de Janeiro: Imago.

Freud, S. (1923/1996). O Ego e o Id. ESB, XIX. Rio de Janeiro: Imago.

Freud, S. (1923/1996). A organização genital infantil: Uma Interpolação na teoria da sexualidade. ESB, XIX. Rio de Janeiro: Imago.

Freud, S. (1924/1996). O problema econômico do masoquismo. ESB, XIX. Rio de Janeiro: Imago.

Freud, S. (1924/1996). A dissolução do complexo de édipo. ESB, XIX. Rio de Janeiro: Imago.

Freud, S. (1924/1996). Neurose e psicose. ESB, XIX. Rio de Janeiro: Imago.

Freud, S. (1925/1996). Algumas conseqüências psíquicas da distinção anatômica entre os sexos. ESB, XIX. Rio de Janeiro: Imago.

Freud, S. (1926/1996). Inibições, sintomas e ansiedade. ESB, XX. Rio de Janeiro: Imago.

Freud, S. (1931/1996). Sexualidade feminina. ESB, XXI. Rio de Janeiro: Imago.

Freud, S. (1933/1996). Conferência XXXI —A dissecção da personalidade psíquica. ESB, XXII. Rio de Janeiro: Imago.

Freud, S. (1933/1996). Conferência XXXII —Ansiedade e Vida Instintual. ESB, XXII. Rio de Janeiro: Imago.

Freud, S. (1933/1996). Conferência XXXIII — Feminilidade. ESB, XXII. Rio de Janeiro: Imago.

Freud, S. (1940/1996). Esboço de psicanálise. ESB, XXIII. Rio de Janeiro: Imago.

Freud, S. (1950/1996). Projeto para uma psicologia científica. ESB, I. Rio de Janeiro: Imago.

Masson, J. M. (1895/1986). The complete correspondence of Sigmund Freud to Wilhelm Fliess 1887-1904. Rio de Janeiro: Imago. Mijolla, A. (2005). International dictionary of psychoanalysis (Translation of Álvaro Cabral). Rio de Janeiro: Imago. 